\title{
Fluorination of Haloaromatic Compounds ${ }^{1,2}$
}

\author{
Roland E. Florin, Walter J. Pummer, and Leo A. Wall
}

\begin{abstract}
The reactions of $\mathrm{BrF}_{3}, \mathrm{ClF}_{3}$, and $\mathrm{IF}_{5}$ with $\mathrm{C}_{6} \mathrm{Cl}_{6}, \mathrm{C}_{6} \mathrm{Br}_{6}, \mathrm{C}_{6} \mathrm{Cl}_{5}-\mathrm{CF}_{3}$, and other haloaromatic compounds are described. These reactions are not readily controlled, and explosions frequently occurred, particularly when $\mathrm{BrF}_{3}$ and $\mathrm{ClF}_{3}$ were used. Dehalogenation of the reaction products led to certain aromatic fluorocarbons, for example, $\mathrm{C}_{6} \mathrm{ClF}_{5}$ and $\mathrm{C}_{6} \mathrm{ClF}_{4}-\mathrm{CF}_{3}$. Completely fluorinated aromatic compounds were not easily obtained, and therefore the process is not recommended for the production of these species.
\end{abstract}

\section{Introduction}

Until the recent disclosure of new methods for preparing hexafluorobenzene $[1-3]^{3}$ the only published syntheses $[4,5]$ of aromatic fluorocarbons were the conversions of hexachlorobenzene to hexafluorobenzene and of pentachloro- $\alpha, \alpha, \alpha$-trifluorotoluene to octafluorotoluene by an indirect procedure involving addition of bromine trifluoride, exchange fluorination with antimony pentafluoride, and dehalogenation with zinc.

Attempts were made to modify the method so as to prepare reactive mono- and bi-functional derivatives, as well as the parent fluorocarbons. For ex ample, it was hoped that the final product in the following scheme would be obtained:

$$
\mathrm{C}_{6} \mathrm{Br}_{6} \stackrel{\mathrm{BrF}_{3}}{\longrightarrow} \mathrm{C}_{6} \mathrm{~F}_{4} \mathrm{Br}_{8} \stackrel{\mathrm{Zn}}{\longrightarrow} \mathrm{C}_{6} \mathrm{~F}_{4} \mathrm{Br}_{2}
$$

Previously, a synthesis of a compound of this type and its conversion to a polyphenyl of low molecular weight was reported [6] from this laboratory. How ever, the synthesis was extremely laborious. The present work was undertaken to find a shorter path to the desired compound, which it is anticipated would lead to the synthesis of thermally stable poly.. mers. The compound prepared earlier was tetrafluoro-1,4-diiodobenzene [6], and in the present work it was expected and hoped that the meta and ortho isomers would also be obtained.

\section{Results and Discussion}

In trying to repeat this previously described prepa-ration, difficulties were experienced in the later, high-temperature stages of the bromine trifluoride reaction. The conditions of temperature and concentration prescribed in the literature led to explosions very frequently, and less severe reaction conditions were insufficient for producing the desired degree of fluorination. It was concluded that the operations described in the original paper are very close to the margin of safety. Milder fluorinations were con-

1 This paper is based on work sponsored by the Ordnance Corps, Department of the Army, Washington, D.C

2 Presented as part of the Symposium on Fluorine Chemistry, Division of Industrial andEngineering Chemistry, at the 130th Meeting of the American Chemical Society, Atlantic City, N.J., September 1956.

3 Figures in brackets indicate the literature references at the end of this paper. ducted with apparent safety, leading ultimately to very poor yields of the fluorocarbons but to satisfactory yields of their monochloro derivatives. The stages of these syntheses are identified in the following summary, in which most formulas represent merely typical or rough average composition:

$$
\mathrm{C}_{6} \mathrm{Cl}_{5}-\mathrm{CF}_{3} \underset{\mathrm{Cold}}{\stackrel{\mathrm{BrF}_{3}}{\longrightarrow}} \mathrm{C}_{6} \mathrm{BrCl}_{4} \mathrm{~F}_{5}-\mathrm{CF}_{3}
$$

II
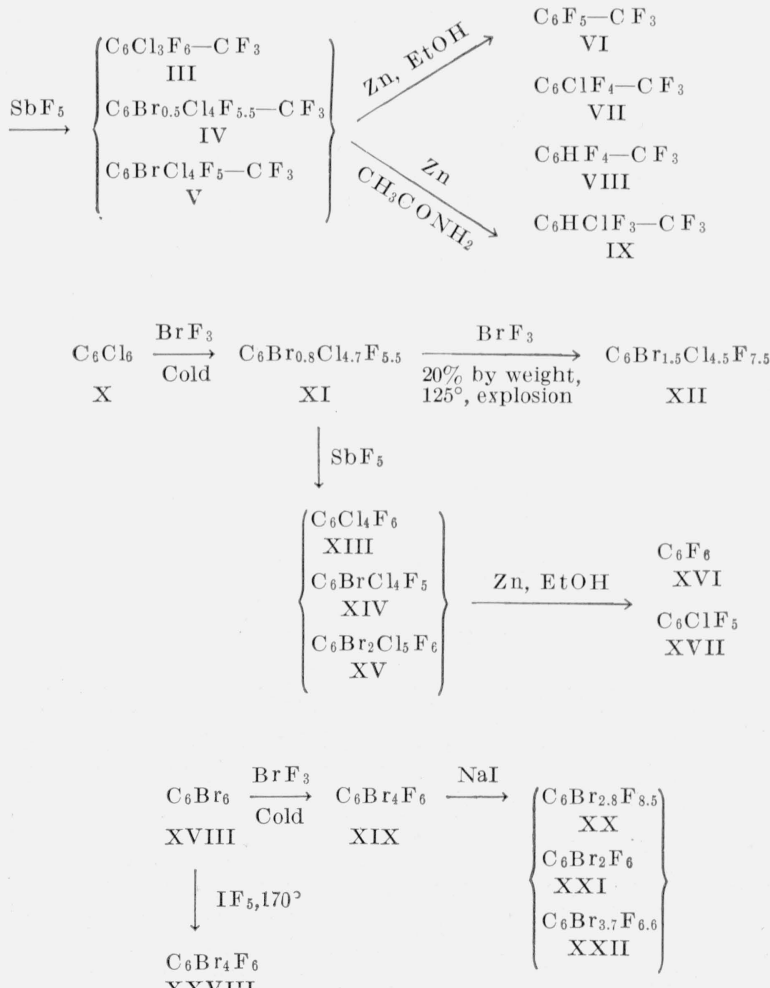

XXVIII

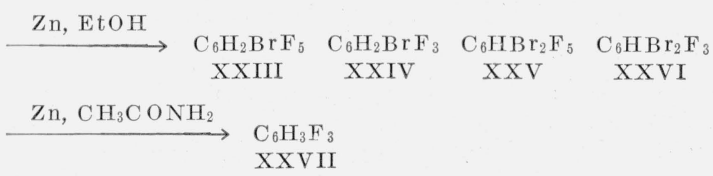


The fluorination of hexabromobenzene proceeded smoothly, but subsequent reactions produced none of the desired perfluoroaromatic derivatives, although several new compounds were isolated. The scheme of synthesis requires that bromine trifluoride react

only by addition, converting the original - $\mathrm{CBr}$ groups to saturated CFBr groups. From the behavior of the fluorination products, it appears that the bulk and lability of bromine hinder addition and favor replacement, leading to unreactive $\mathrm{CF}_{2}$ groups.

The following scheme accounts for some of the products:
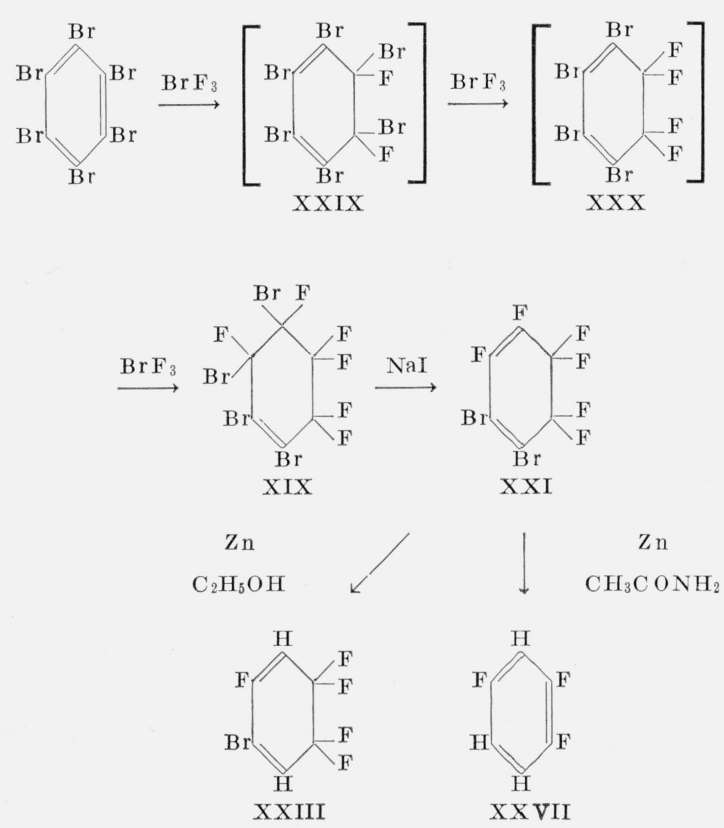

$\mathrm{Zn}$

$\mathrm{CH}_{3} \mathrm{CONH}_{2}$

The hypothetical primary product XXIX contains "allylic" bromine atoms, easily replaced.

A number of other polyhalogen derivatives of benzene were treated with halogen fluorides as well. The products from tetrahalobenzenes resembled those from the related hexahalobenzenes, but the fluorination was less easily managed. It was noticed that, during the zinc dehalogenation stage, some hydrogen is introduced into the ring when ethanol is the solvent; this occurs to a much greater extent with acetamide as solvent. The dehalogenation in acetamide of one lot of intermediate, approximately $\mathrm{C}_{6} \mathrm{Br}_{2} \mathrm{~F}_{6}$ (XXI), resulted in a large yield of a trifluorobenzene, boiling point $83^{\circ} \mathrm{C}$, identified by its ultraviolet and mass spectra. The precursor of the trifluorobenzene is not clear. Its formation probably involves the replacement of "aromatic" or "unsaturated" bromine by hydrogen. This replacement is known to be effected by zinc plus mild acid [7] and occasionally by the action of bases on "aromatic" bromine [8]. In aliphatic fluorocarbons, the replacement of halogen by hydrogen has also been reported by Miller [9].

\subsection{Fluorinations with Halogen Fluorides}

The procedures for hexachlorobenzene and pentachloro- $\alpha, \alpha, \alpha$-trifluorotoluene were much alike throughout and are therefore described together. The hexachlorobenzene was a commercial product; the pentachloro- $\alpha, \alpha, \alpha$-trifluorotoluene was a semiliquid slush or wet crystalline mass obtained by exhaustive chlorination of $\alpha, \alpha, \alpha$-trifluorotoluene [10]. The bromine trifluoride was a commercial product, from several sources, used without purification.

The originally described procedure involved the slow addition of halocarbon to excess bromine trifluoride, in the cold in several portions, with intermittent heating to $100^{\circ} \mathrm{C}$ after addition of each portion. Two attempts to repeat the procedure led to destructive explosions in the later heating stages. Some of the associated patent specifications suggest other operating conditions [5]. A limited proportion of bromine trifluoride could be reacted smoothly with the halocarbon feed by adding the bromine trifluoride slowly to a stirred slurry of the halocarbon in liquid bromine.

Two forms of apparatus were used for different batch sizes. For batches of up to $500 \mathrm{~g}$ of halocarbon, the feed slurry was contained in a 500-ml nickel beaker in an ice bath, and stirred with a 1/8-hp stirrer. Bromine trifluoride was dripped in from a copper separatory funnel with a brass needle valve, in which the packing was replaced by Teflon and located on the downstream side, while the delivery tube was long and offset, to allow safe manipulation of the valve. Addition of bromine trifluoride usually required about 4 to $6 \mathrm{hr}$ per batch. Operation was usually conducted outside the building when weather permitted, although in the laboratory a hood with good draft was sometimes used. Warm, humid weather was undesirable, as the condensation of water in the mixture led to waste of bromine trifluoride, excess heat, and accelerated corrosion. In equipment of this size, reaction began energetically and proceeded relatively smoothly until the addition of 1.6 to 1.8 moles of bromine trifluoride per mole of hexachlorobenzene or pentachloro- $\alpha, \alpha, \alpha$-trifluorotoluene had been completed. After this point, reaction became very slow or ceased. A slight excess of bromine trifluoride appeared to remain unreacted after warming to $20^{\circ}$ to $30^{\circ} \mathrm{C}$ and standing covered overnight.

Large batches $(6 \mathrm{~kg})$ of pentachloro- $\alpha, \alpha, \alpha$-trifluorotoluene were fluorinated in a larger apparatus consisting of a welded Monel can of about 4-liter capacity with widened top to retain foam, a 15-gal ice bath, a 1-liter Monel separatory funnel, and a $3 / 4$-hp stirrer. This reaction vessel was monitored by a thermocouple and automatic recorder. The operator was shielded and remained at a distance, except for short trips to change valve settings or to 
add ice to the bath. The course of reaction in this equipment was not quite consistent with observations in the smaller system. The temperature record on the chart was zigzagged, fluctuating between $+10^{\circ}$ and $+80^{\circ} \mathrm{C}$. An accumulation of bromine trifluoride in the cold alternated with a relatively rapid reaction (and temperature rise) which temporarily exhausted the bromine trifluoride and thus allowed the mixture to cool. Usually, the bromine trifluoride valve was turned off as soon as a sharp temperature rise began. When the flow was resumed before excessive cooling had ensued, accumulation of bromine trifluoride was lessened; and, with the best management, preparation of a large batch was completed in only $3 \mathrm{hr}$. Because of the great fluctuations observed, it is uncertain whether any of the large batches reached the same end point as the small batches.

There is a possibility that halogen replacement and chain-scission reactions could continue indefinitely, leading to $\mathrm{CF}_{4}$ as the end product. However, carbon balances showed that loss of carbon in volatile form amounted, at most, to a very small percentage in the fluorination of pentachloro $\alpha, \alpha, \alpha,-$ trifluorotoluene, although it may have reached 8 percent with hexabromobenzene. It seems obvious that a large batch should not be started too cold, and that it would be quite hazardous to add very much bromine trifluoride until after the occurrence of some temperature rise that indicates the initiation of normal reaction.

Partial fluorinations were conducted upon some 30 small batches and 4 large batches involving, in all, $27 \mathrm{~kg}$ of pentachloro- $\alpha, \alpha, \alpha$-trifluorotoluene, $4 \mathrm{~kg}$ of hexachlorobenzene, and $5 \mathrm{~kg}$ of hexabromobenzene. No explosions occurred in this stage, although the sharp rises in temperature observed. with the large batches suggest that this might be possible with poor management. The character of products from this stage is shown in table 1 . The analyses indicate that the present chlorofluoro intermediates, as obtained from this work, are less highly fluorinated and less saturated than those in the literature. It appeared desirable to saturate the materials to the highest possible extent, as any double bonds would lack fluorine atoms needed later, and would probably fail to take up fluorine in the exchange-fluorination step. Accordingly, the clear liquid products of the first step were mixed with more bromine trifluoride and heated to above $100^{\circ} \mathrm{C}$, but with disappointing results.
Mixtures containing less than 10 to 15 percent by weight of bromine trifluoride, heated to $110^{\circ}$ to $115^{\circ} \mathrm{C}$ for $6 \mathrm{hr}$, appeared to lose the fluorinating agent by evaporation, and the analysis and properties were unchanged. Mixtures containing 20 percent by weight of bromine trifluoride, heated to $120^{\circ}$ to $130^{\circ} \mathrm{C}$, appeared inert until a sudden explosive reaction occurred, vaporizing and spattering the product. In one instance, an explosion of material derived from hexachlorobenzene allowed about a 20 percent recovery of a clean, waxy, crystalline product, XII, probably similar to that mentioned in the literature [4]. Further high-temperature reactions were abandoned.

Other expedients found ineffective were the incorporation of small proportions of cobalt, lead, or manganese as possible catalysts, and, also, long exposure to fluorine gas at $25^{\circ} \mathrm{C}$. When selected, high-boiling low-fluorine material derived from pentachloro- $\alpha, \alpha, \alpha$-trifluorotoluene (II, V) was mixed with bromine trifluoride to form a clear solution, exposure to bright sunlight caused slow formation of bromine and evolution of heat. A low-boiling, highfluorine fraction (III) did not react under the same conditions, although its analysis indicated some unsaturation. Chlorine trifluoride was able to react with these first-stage products (II). Bromine was evolved at first, and the mixture later became clear. The change in properties was, however, minor and the yield of fluoroaromatic products from a trial batch was not notably improved. An attempt to introduce chlorine trifluoride into cold, previously fluorinated material resulted in accumulation without reaction until an explosion destroyed the mixture. The method was not pursued further, despite its possible merits.

\subsection{Hexafluorobenzene, Octafluorotoluene, and Some Chloro Derivatives}

From the composition of intermediates quoted in the literature, it was hoped that the fluorinated materials could be dehalogenated without the intervention of an antimony pentafluoride reaction. When this step was omitted, however, the yield of product boiling under $145^{\circ} \mathrm{C}$ was nil; therefore antimony pentafluoride was used as prescribed. The reaction product was sometimes distilled to yield the rough fractions shown in tables 2 and 3 , and was sometimes steam-distilled. A steam distillation residue, 40 percent by weight, yielded no useful low-boiling products upon subsequent dehalogenation.

TABLE 1. Fluorination stages for pentachloro- $\alpha, \alpha, \alpha$-trifluorotoluene

\begin{tabular}{|c|c|c|c|c|c|c|}
\hline Reaction & Fluorinating agent & Halocarbon & Product formula a & Weight & $\mathrm{d}_{4}^{24}$ & $n_{\mathrm{D}}^{24}$ \\
\hline$a_{-}$ & $\mathrm{BrF}_{3}$, cold, $4,800 \mathrm{~g}$ & $\mathrm{C}_{6} \mathrm{Cl}_{5}-\mathrm{CF}_{3}, 5,600 \mathrm{~g}$ & $\mathrm{C}_{7} \mathrm{Br}_{0.8} \mathrm{Cl}_{3.7} \mathrm{~F}_{7.8}$ & $7, \frac{g}{600}$ & 2. 00 & 1.4536 \\
\hline$b_{-}$ & $\mathrm{BrF}_{3}$, hot, $200 \mathrm{~g}$ & IIa, b $950 \mathrm{~g}$ & $\mathrm{C}_{7} \mathrm{Br}_{0.8} \mathrm{Cl}_{3.2} \mathrm{~F}_{8.2}$ & 813 & 1.99 & 1. 4532 \\
\hline c-... & $\mathrm{SbF}_{5}, 1,300 \mathrm{~g}$ & $\mathrm{IIb},{ }^{\mathrm{c}} 3,234 \mathrm{~g}$ & $\mathrm{C}_{7} \mathrm{Br}_{0.5} \mathrm{Cl}_{3.5} \mathrm{~F}_{9.0}$ & 2,890 & 1.87 & 1.4186 \\
\hline
\end{tabular}

a Average composition.

c Product from reaction (b). 
TABLE 2. Fractions of fluorinated hexachlorobenzene after treatment with antimony pentafluoride

\begin{tabular}{|c|c|c|c|c|c|c|c|c|}
\hline \multirow{2}{*}{$\begin{array}{c}\text { Num- } \\
\text { ber }\end{array}$} & \multirow{2}{*}{$\begin{array}{c}\text { Boiling } \\
\text { point }\end{array}$} & \multirow{2}{*}{ Weight } & \multirow{2}{*}{$\mathrm{d}_{4}^{20}$} & \multirow{2}{*}{$n_{\mathrm{D}}^{24}$} & \multicolumn{4}{|c|}{ Gross composition } \\
\hline & & & & & C & $\mathrm{Br}$ & $\mathrm{Cl}$ & $\mathrm{F}$ \\
\hline $\begin{array}{l}\text { XIII } \\
\text { XIV }\end{array}$ & $\begin{array}{c}\circ \mathrm{C} / \mathrm{mm} \\
50 \text { to } 90 / 7 \\
90 \text { to } 105 / 7\end{array}$ & $\begin{array}{c}g \\
1,427 \\
1,202\end{array}$ & $\begin{array}{l}\text { 1. } 87 \\
\text { 2. } 00\end{array}$ & $\begin{array}{l}\text { 1. } 4427 \\
\text { 1. } 4749\end{array}$ & $\begin{array}{l}6 \\
6\end{array}$ & $\begin{array}{r}0.3 \\
.9\end{array}$ & $\begin{array}{l}4.0 \\
4.5\end{array}$ & $\begin{array}{l}6.2 \\
5.2\end{array}$ \\
\hline $\mathrm{XV}$ & 105 to $115 / 7$ & 200 & & & 6 & 1.2 & 4.7 & 6.0 \\
\hline
\end{tabular}

TABLE 3. Fractions of fluorinated pentachloro- $\alpha, \alpha, \alpha$-trifuorotoluene after treatment with antimony pentafluoride

\begin{tabular}{|c|c|c|c|c|c|c|c|c|}
\hline \multirow{2}{*}{$\underset{\text { ber }}{\text { Num- }}$} & \multirow{2}{*}{$\begin{array}{l}\text { Boiling } \\
\text { point }\end{array}$} & \multirow{2}{*}{ Weight } & \multirow{2}{*}{$\mathrm{d}_{4}^{24}$} & \multirow{2}{*}{$n_{\mathrm{D}}^{24}$} & \multicolumn{4}{|c|}{ Gross composition } \\
\hline & & & & & $\mathrm{C}$ & $\mathrm{Br}$ & $\mathrm{Cl}$ & $\mathrm{F}$ \\
\hline $\begin{array}{l}\text { III } \\
\text { IV } \\
\text { V }\end{array}$ & $\begin{array}{c}{ }^{\circ} \mathrm{C} / \mathrm{mm} \\
25 \text { to } 70 / 10 \\
71 \text { to } 80 / 10 \\
60 \text { to } 115 / 2\end{array}$ & $\begin{array}{c}g \\
2,460 \\
1,430 \\
1,347\end{array}$ & $\begin{array}{l}\text { 1. } 836 \\
1.882 \\
1.998\end{array}$ & $\begin{array}{l}\text { 1. } 4016 \\
\text { 1. } 4239 \\
\text { 1. } 4470\end{array}$ & $\begin{array}{l}7 \\
7 \\
7\end{array}$ & $\begin{array}{r}0.1 \\
.4 \\
.8\end{array}$ & $\begin{array}{l}3.3 \\
3.7 \\
3.9\end{array}$ & $\begin{array}{l}9.1 \\
8.5 \\
7.8\end{array}$ \\
\hline
\end{tabular}

Dehalogenation in ethanol was conducted as described in the literature [4]. Higher-boiling residues from this step were then dehalogenated in acetamide. The dehalogenation in ethanol furnished relatively pure perhaloaromatic compounds (VI, VII, XVII), but corresponding fractions from the acetamide operation were heavily contaminated with hydrogen compounds (VIII, IX), as indicated by mass spectra, higher refractive index, and lower density. Products of the two operations are compared in table 4 . All of the octafluorotoluene was highly contaminated with heptafluorotoluene. The combined product apparently contained about 48 percent $\mathrm{C}_{6} \mathrm{~F}_{5} \mathrm{CF}_{3}$ and 50 percent $\mathrm{C}_{6} \mathrm{~F}_{4} \mathrm{HCF}_{3}$. Iodination of the mixture in fuming sulfuric acid converted the latter component into nearly pure 2-iodoheptafluorotoluene. The perfluorotoluene, which did not react, was subsequently hydrolyzed, yielding pentafluorobenzene.

TABLE 4. Fluoroaromatic compounds from ethanol and acetamide dehalogenations

\begin{tabular}{|c|c|c|c|c|c|c|}
\hline \multirow{2}{*}{$\begin{array}{l}\text { Boiling } \\
\text { range }\end{array}$} & \multirow{2}{*}{$\begin{array}{l}\text { Nominal } \\
\text { formula }\end{array}$} & \multicolumn{2}{|c|}{ From ethanol } & \multicolumn{2}{|c|}{ From acetamide } & \multirow{2}{*}{ Identification } \\
\hline & & $d_{4}^{26}$ & $n_{\mathrm{D}}^{26}$ & $\mathrm{~d}_{4}^{26}$ & $n_{\mathrm{D}}^{26}$ & \\
\hline $\begin{array}{c}{ }^{\circ} C \\
80 \text { to } 83 \\
119 \text { to } 124 \\
102 \text { to } 111 \\
138 \text { to } 139\end{array}$ & $\begin{array}{c}\mathrm{C}_{6} \mathrm{~F}_{6} \\
\mathrm{C}_{6} \mathrm{ClF}_{5} \\
\mathrm{Cl}_{7} \mathrm{~F}_{8} \\
\mathrm{C}_{7} \mathrm{ClF}_{7}\end{array}$ & $\begin{array}{l}\text { 1. } 628 \\
\text { 1. } 672 \\
\text { 1. } 61 \\
1.67\end{array}$ & 1.3640 & $\begin{array}{l}\text { 1. } 52 \\
\text { 1. } 576 \\
1.50 \\
1.58\end{array}$ & 1. 3704 & $\begin{array}{l}\text { XVI, XVIa } \\
\text { XVII, XVIIa } \\
\text { VI, VIII } \\
\text { VII, IX }\end{array}$ \\
\hline
\end{tabular}

An examination of the chloroheptafluorotoluene by nuclear magnetic resonance, for which the authors are indebted to H. S. Gutowsky of the University of Illinois, indicated predominantly 2 -chloroheptafluorotoluene with about 15 percent of another isomer, probably 4-chloroheptafluorotoluene.

The structure of the chloroheptafluorotoluene was further established as having the chlorine atom ortho [11] to the trifluoromethyl group by conversion to 1,2,3,4-tetrafluorobenzene. The ortho structure shows that fluorine atoms usually failed to add ortho to the trifluoromethyl group of the starting material, probably because of steric hindrance.

\section{Experimental Procedure}

\subsection{Hexachlorobenzene and Bromine Trifluoride}

A mixture of $100 \mathrm{~g}$ of hexachlorobenzene and $200 \mathrm{~g}$ of bromine was stirred in a 500-ml nickel beaker, surrounded by an ice bath. A supply of $264 \mathrm{~g}$ (1.92 moles) of bromine trifluoride was placed in a copper separatory funnel and about $50 \mathrm{~g}$ of this supply was dripped in slowly, with stirring, until the slurry had become nearly liquid. Further increments of hexachlorobenzene were added, followed by minor additions of bromine trifluoride, until a total of $285 \mathrm{~g}$ (1.00 mole) of hexafluorobenzene and about $150 \mathrm{~g}$ of bromine trifluoride had been added. The remaining bromine trifluoride was then slowly added. The total addition occupied $3 \mathrm{hr}$; stirring was continued overnight. Bromine and excess bromine trifluoride volatilized, leaving $340 \mathrm{~g}$ of a clear liquid, $\mathrm{d}_{4}^{25} 1.993$.

Analysis: Found: C, $17.2 ; \mathrm{Br}, 15.9 ; \mathrm{Cl}, 40.6$; F, 25.0.

\subsection{Pentachloro- $\alpha, \alpha, \alpha$-trifluorotoluene and Bromine Trifluoride (large batch)}

In a Monel reactor having a 3.5-liter well and fitted with a $3 / 4$-hp stirrer was placed $5.72 \mathrm{~kg}(18.0$ moles) of crude pentachloro- $\alpha, \alpha, \alpha$-trifluorotoluene. From a large Monel separatory funnel, $4.3 \mathrm{~kg}$ (31.4 moles) of bromine trifluoride was added to the stirred halocarbon over a period of $6 \mathrm{hr}$. The reactor was surrounded by crushed ice in a 15-gal can. A distant thermocouple recorder showed temperature fluctuations between $+10^{\circ}$ and $+50^{\circ} \mathrm{C}$. The liquid product weighed $8.48 \mathrm{~kg}$.

In the large-scale work with pentachloro- $\alpha, \alpha, \alpha$ trifluorotoluene a total of $21.60 \mathrm{~kg}$ (67.7 moles) of pentachloro- $\alpha, \alpha, \alpha$-trifluorotoluene and $15.54 \mathrm{~kg}(113$ moles) of bromine trifluoride were reacted to yield $30.42 \mathrm{~kg}$ of fluorination product (II). Of this quantity, $28.5 \mathrm{~kg}$ was treated with $12.3 \mathrm{~kg}$ (57 moles) of antimony pentafluoride, giving a recovery of $20.2 \mathrm{~kg}$ of product (III-V). The product was dehalogenated with $16.1 \mathrm{~kg}$ of zinc in ethanol, the recovery being $12.38 \mathrm{~kg}$ of dehalogenated material, which yielded upon distillation $656 \mathrm{~g}$ (about 2.7 moles) of mixed polyflurotoluenes (VI), 4,895 kg (18.7 moles) of 2-chloro- $\alpha, \alpha, \alpha, 3,4,5,6$-heptafluorotoluene (VII), and $5.5 \mathrm{~kg}$ of residue. The smaller operations with $4 \mathrm{~kg}$ of hexachlorobenzene yielded about $25 \mathrm{~g}$ (about $1 \%$ ) of crude hexafluorobenzene (XVI) and $307 \mathrm{~g}$ (about $12 \%$ ) of chloropentafluorobenzene (XVII).

\subsection{Hexabromobenzene and Bromine Trifluoride}

In a $500-\mathrm{ml}$ nickel beaker cooled in an ice bath were placed $138 \mathrm{~g}$ ( 0.25 mole) of hexabromobenzene and $100 \mathrm{ml}$ of bromine. During $3 \mathrm{hr}$, a mixture of $53 \mathrm{~g}$ 
(0.38 mole) of bromine trifluoride and an equal volume of bromine was added from a copper separatory funnel with stirring. The product (XIX) which formed during the addition weighed $62.5 \mathrm{~g}$ and consisted of clear, oily liquid and crystals. It distilled with decomposition at $200^{\circ}$ to $250^{\circ} \mathrm{C}$ under atmospheric pressure, evolving large amounts of bromine. Partial distillation with less decomposition occurred at 1 to $2 \mathrm{~mm}$.

Analysis: Calculated for $\mathrm{C}_{6} \mathrm{Br}_{4} \mathrm{~F}_{6}$ : C, $14.2 ; \mathrm{Br}$, 63.2 ; F, 22.5. Found: Liquid-C, $14.1 ; \mathrm{Br}, 63.6$; F, 19.7. Crystals - C, $14.0 ; \mathrm{Br}, 66.0 ; \mathrm{F}, 17.7$.

Another experiment used $552 \mathrm{~g}$ (1 mole) of hexabromobenzene and $274 \mathrm{~g}$ ( 2 moles) of bromine trifluoride. Half of the hexabromobenzene was put in the beaker, stirred with $300 \mathrm{~g}$ bromine, and onequarter of the bromine trifluoride was added gradually, causing the mixture to become almost completely liquid. The remaining hexabromobenzene was then added, followed gradually by the remaining bromine trifluoride. The operation required $6 \mathrm{hr}$. After evaporation of volatile substances, the yield was $445 \mathrm{~g}$ of clear liquid, $\mathrm{d}_{4}^{25}$ 2.65. Table 5 gives a resume of these fluorination products (XIXa to d, XXVIII).

TABLE 5. Fluorination of hexabromobenzene

\begin{tabular}{|c|c|c|c|c|c|c|c|c|}
\hline \multirow{2}{*}{ Agent } & \multirow{2}{*}{$\begin{array}{l}\text { Mole } \\
\text { ratio: } \\
\mathrm{Br} \mathrm{F}_{3} / \\
\mathrm{C}_{6} \mathrm{Br}_{6}\end{array}$} & \multirow{2}{*}{ Yield } & \multirow{2}{*}{$\mathrm{d}_{4}^{24}$} & \multirow{2}{*}{$n_{\mathrm{D}}^{24}$} & \multicolumn{3}{|c|}{ Gross composition } & \multirow{2}{*}{$\begin{array}{l}\text { Identifi- } \\
\text { cation }\end{array}$} \\
\hline & & & & & $\mathrm{C}$ & $\mathrm{Br}$ & $\mathrm{F}$ & \\
\hline $\begin{array}{l}\mathrm{BrF}_{3} \\
\mathrm{BrF}_{3} \\
\mathrm{BrF}_{3} \\
\mathrm{BrF}_{3} \\
\mathrm{IF}_{5}\end{array}$ & $\begin{array}{l}3 \\
1.5 \\
2 \\
1.7 \\
a 5\end{array}$ & $\begin{array}{r}\text { wo } \% \\
56 \\
45 \\
82 \\
82 \\
\sim 50\end{array}$ & $\begin{array}{l}2.58 \\
2.65 \\
2.68 \\
2.4\end{array}$ & $\begin{array}{l}\text { 1. } 4248 \\
\text { 1. } 4682 \\
\text { 1. } 5342 \\
1.4913\end{array}$ & $\begin{array}{l}6 \\
6 \\
6 \\
-6 \\
6\end{array}$ & $\begin{array}{l}\text { 4. } 0 \\
4.0 \\
4.0 \\
3.3\end{array}$ & $\begin{array}{l}5.9 \\
5.3 \\
3.5 \\
\overline{6} .1\end{array}$ & $\begin{array}{l}\text { XIXa } \\
\text { XIXb } \\
\text { XIXe } \\
\text { XIXd } \\
\text { XXVIII }\end{array}$ \\
\hline
\end{tabular}

a Fluorinating agent to hexabromobenzene.

\subsection{Hexabromobenzene and Iodine Pentafluoride}

In a Monel bomb of about 40-ml capacity, a mixture of $30 \mathrm{~g}$ (0.05 mole) of hexabromobenzene and $54 \mathrm{~g}$ (0.24 mole) of iodine pentafluoride was heated for 80 hr at $170^{\circ} \mathrm{C}$. The product, after removal of iodine by thiosulfate, consisted of $18 \mathrm{~g}$ of mobile liquid (XXVIII), d ${ }_{4}^{25} 2.4, n_{\mathrm{D}}^{20} 1.4913$.

Analysis: Calculated for $\mathrm{C}_{6} \mathrm{Br}_{4} \mathrm{~F}_{6}$ : C, $14.20 ; \mathrm{Br}$, $63.2 ; \mathrm{F}, 22.5$. Found: C, $15.4 ; \mathrm{Br}, 56.4 ; \mathrm{F}, 24.9$. A larger batch consisting of 0.5 mole of $\mathrm{C}_{6} \mathrm{Br}_{6}$ and 0.5 mole of $\mathrm{IF}_{5}$, heated under the same conditions, suddenly evolved bromine, causing the bomb to open and leaving a nearly stoichiometric residue of carbon. No reaction occurred at $96^{\circ}$.

\subsection{Iodide Dehalogenations}

To a solution of $515 \mathrm{~g}$ (3.4 moles) of sodium iodide in 1 liter of acetone in an Erlenmeyer flask was added $400 \mathrm{~g}$ of crude fluorination product (XIX) of density 2.65. The mixture was stoppered and left overnight with occasional shaking. After pouring onto ice and removing iodine with bisulfite and thiosulfate, the product was dried and distilled, yielding (XX) 13.5 g, bp $100^{\circ} / 35 \mathrm{~mm}, \mathrm{~d}_{4}^{25} 2.09, n_{\mathrm{D}}^{24} 1.4426$; molecular weight (in benzene), 380; (XXI) $185 \mathrm{~g}$, bp $111^{\circ}$ to $113^{\circ} \mathrm{C} / 35 \mathrm{~mm}, \mathrm{~d}_{4}^{25} 2.39, n_{\mathrm{D}}^{24} 1.4964, \mathrm{mp}-15^{\circ}$ to $-17^{\circ} \mathrm{C}$, molecular weight (in benzene), 420 ; (XXII) $59 \mathrm{~g}$, bp $95^{\circ}$ to $100^{\circ} / 5 \mathrm{~mm}, \mathrm{~d}_{4}^{25} 2.56$. Fraction (XXII) deposited crystals in the receiver. The analysis of (XXI) suggested that it might be impure $\mathrm{C}_{6} \mathrm{Br}_{2} \mathrm{~F}_{6}$. As a byproduct, a $660-\mathrm{g}$ sample of fluorination product liberated 1 mole of iodine and no fluoride ions.

\subsection{Acetamide Dehalogenation}

To a three-necked flask containing $95 \mathrm{~g}$ of zinc dust and $20 \mathrm{~g}$ of sodium iodide in $300 \mathrm{~g}$ of acetamide at $100^{\circ} \mathrm{C}, 200 \mathrm{~g}$ of fraction XXI (preceding paragraph) was slowly added. The product, bp $83^{\circ}$, amounted to $50 \mathrm{~g}$, had $\mathrm{d}_{4}^{25} 1.28$ to 1.32 , and showed the mass spectrometer peaks and ultraviolet absorption characteristics of impure 1,3,4-trifluorobenzene (XXVII).

\subsection{Ethanol Dehalogenation}

Absolute alcohol $(700 \mathrm{ml})$ and $81.07 \mathrm{~g}$ of zinc dust were stirred in a large three-necked flask, and $310 \mathrm{~g}$ of fraction XXI was gradually added. The crude untreated products (XIX), from the reaction of a total of $4.5 \mathrm{~kg}$ (8.15 moles) of hexabromobenzene with bromine trifluoride, were processed likewise. The total product was fractionally distilled in a jacketed column. The principal fractions were (XXIII) $121.6 \mathrm{~g}$ (0.48 mole), $\mathrm{C}_{6} \mathrm{H}_{2} \mathrm{BrF}_{5}$, bp $121^{\circ}$ to $123^{\circ} \mathrm{C}, \mathrm{d}_{4}^{25} 1.78, n_{\mathrm{D}}^{25} 1.4080$; (XXIV) $11.5 \mathrm{~g}$ (0.05 mole) impure $\mathrm{C}_{6} \mathrm{H}_{2} \mathrm{BrF}_{3}$, bp $144^{\circ}$ to $146^{\circ}$; (XXV) $225 \mathrm{~g}$ (about 0.70 mole) of a fraction mainly consisting of $\mathrm{C}_{6} \mathrm{H}_{2} \mathrm{Br}_{2} \mathrm{~F}_{4}$ and $\mathrm{C}_{6} \mathrm{Br}_{2} \mathrm{~F}_{6}$, bp $164^{\circ}$ to $169^{\circ} / 750 \mathrm{~mm}, 60^{\circ}$ to $64^{\circ} / 10 \mathrm{~mm}, \mathrm{~d}_{4}^{25} 2.09, n_{\mathrm{D}}^{25} 1.4565$, mp $-7.5^{\circ}$; and (XXVI) $20 \mathrm{~g}$ of higher-boiling material, bp $80^{\circ}$ to $82^{\circ} / 10 \mathrm{~mm}, \mathrm{~d}_{4}^{25} 2.21$. Fraction XXIV was identified by mass spectrometer.

Analysis: Found for XXIII: C, 28.5; H, 0.8; $\mathrm{Br}, 32.3 ; \mathrm{F}$ ，38.3. Calculated for $\mathrm{C}_{6} \mathrm{H}_{2} \mathrm{BrF}_{5}$ : C, $28.9 ; \mathrm{H}, 0.8 ; \mathrm{Br}, 32.3 ; \mathrm{F}, 38.2$. Found for XXV: $\mathrm{C}, 21.0 ; \mathrm{H}, 0.6 ; \mathrm{Br}, 48.5 ; \mathrm{F}, 28.6$. Calculated for $\mathrm{C}_{6} \mathrm{HBr}_{2} \mathrm{~F}_{5}$ : C， 22.0; H, 0.3; Br, 48.9; F, 29.0. Found for XXVI: C, $22.3 ; \mathrm{H}, 0.4 ; \mathrm{Br}, 55.6 ; \mathrm{F}, 21.5$.

\subsection{Bromine Trifluoride and Chloranil}

Chloranil, $123 \mathrm{~g}$ (0.5 mole), was stirred in a nickel beaker with $200 \mathrm{ml}$ of bromine while being cooled in an ice bath. Bromine trifluoride, $100 \mathrm{~g}$ (0.75 mole), prediluted with $100 \mathrm{ml}$ of bromine, was gradually dropped in over a period of $4 \mathrm{hr}$. The product, $130 \mathrm{~g}$, was filtered to yield crystals and an oil. The crystals, after washing with ligroin and recrystallizing from methanol, melted at $64^{\circ}$ to $65.5^{\circ}$. The oil distilled at $50^{\circ}$ to $98^{\circ}$ under $1 \mathrm{~mm}$ pressure, and had $\mathrm{d}_{4}^{25}$ 2.04. A small sample of the crystals, treated with zinc in ethanol and then oxidized with nitric acid, yielded trichloroquinone.

Analysis: Found for crystals: C, $21.0 ; \mathrm{Br}, 23.7$; $\mathrm{Cl}, 40.7 ; \mathrm{F}$, 5.9. Calculated for $\mathrm{C}_{6} \mathrm{BrCl}_{4} \mathrm{FO}_{2}$ : C, $20.8 ; \mathrm{Br}, 23.2 ; \mathrm{Cl}, 41.2 ; \mathrm{F}, 5.5$. Found for oil: C, $18.2 ; \mathrm{Br}, 26.7 ; \mathrm{Cl}, 32.5 ; \mathrm{F}, 13.0$. Calculated for $\mathrm{C}_{6} \mathrm{BrCl}_{4} \mathrm{~F}_{3} \mathrm{O}_{2}: \mathrm{C}, 18.8 ; \mathrm{Br}, 20.9 ; \mathrm{Cl}, 37.0 ; \mathrm{F}, 14.9$. 


\section{References}

[1] Y. Desirant, Bull. classe sci., Acad. roy. Belg. [5] 41, 759 (1955).

[2] M. Hellmann, E. Peters. W. J. Pummer, and L. A. Wall, J. Am. Chem. Soc. 79, 5654 (1957).

[3] J. A. Godsell, M. Stacey, and J. C. Tatlow, Nature 178, 199 (1956).

[4] E. T. McBee, V. V. Lindgren, and W. B. Ligett, Ind. Eng. Chem. 39, 378 (1947).

[5] E. T. MeBee, V. V. Lindgren, and W. B. Ligett, U.S. Patents 2,461,554, Feb. 15, 1949; 2,471,831, May 31, $1949 ; 2,480,080$, Aug. 23, 1949; 2,488,216, Nov. 15, 1949; 2,489,969, Nov. 29, 1949; and 2,498,891, Feb. 28, 1950 .

[6] M. Hellmann, A. J. Bilbo, and W. J. Pummer, J. Am. Chem. Soc. 7\%, 3650 (1955).
[7] B. Bak, D. Christensen, J. Rastrup-Andersen, Eileen Tannenbaum, and L. Hansen-Nygaard, J. Chem. Phys. 25, 893 (1956); ibid. 26, 135 (1957).

[8] T. van der Linden, Rec. trav. chim. 5\%, 781 (1938).

[9] W. T. Miller, E. Bergman, and A. H. Fainberg, J. Am. Chem. Soc. 79, 4159 (1957)

[10] E. T. MeBee, J. S. Neweomer, W. E. Burt, and Z. D. Welch, Chapter on Preparation, properties, and technology of fluorine and organic fluorine compounds, Charles Slesser, ed., National Nuclear Energy Series, p. 783 (McGraw-Hill Publishers, New York, N.Y.).

[11] W. J. Pummer, R. E. Florin, and L. A. Wall, J Research NBS 62, (1959) RP2939.

Washington, June 20, 1958. 